Original Article

\title{
EVALUATION OF GASTROPROTECTIVE EFFECTS OF METHANOL EXTRACT OF TEPHROSIA VILLOSA AGAINST EXPERIMENTALLY INDUCED ULCERS IN WISTAR RATS
}

\author{
PINKEY RAWAL ${ }^{1}$, RAMESH C. ${ }^{2 *}$, SOMA PRAMANIK ${ }^{1}$ \\ 1Department of Pharmaceutical Chemistry, East West College of Pharmacy, Bangalore 560091, 2Department of Pharmacology, East West \\ College of Pharmacy, Bangalore 560091 \\ Email: rameshcology80@gmail.com
}

Received: 02 Mar 2021, Revised and Accepted: 21 Sep 2021

ABSTRACT

Objective: The present research work was designed to investigate the gastroprotective potentials of methanol extract of Tephrosia villosa.

Methods: The aerial parts of Tephrosia villosa were dried under shade, powdered and deffated with petroleum ether and then marc leftover was subjected to methanol extraction using soxhlet apparatus using soxh-let apparatus. Antiulcer activity of methanol extract was determined against stress-induced and aspirin-induced ulcers in experimental animal models. The total number of ulcers formed, ulcer index, percentage inhibition, ulcerated area, protected area, $\mathrm{pH}$ and Total acidity were parameters in the study.

Results: Methanol extract of Tephrosia villosa at medium $(200 \mathrm{mg} / \mathrm{kg})$ and high $(200 \mathrm{mg} / \mathrm{kg})$ could significantly $(\mathrm{P}<0.01)$ reduced the total number of ulcers formed, ulcer index, ulcerated area and total acidity in therapeutic groups compared to vehicle control and thereby significantly $(\mathrm{P}<0.01)$ increased percentage inhibition of ulcers and protected area which was evident by the significant rise in $\mathrm{pH}$ of gastric content. The effect of extracts was dose-dependent and results were comparable to that of standard drug omeprazole.

Conclusion: The results obtained from the present work suggest that the methanol extract of Tephrosia villosa possess significant anti-ulcer potentials against experimentally induced ulcers in albino rats.

Keywords: Tephrosia villosa, Anti-ulcer activity, Ethanol, Aspirin Ulcer index, pH, Total acidity, Percentage inhibition and percentage of protected area

(c) 2021 The Authors. Published by Innovare Academic Sciences Pvt Ltd. This is an open access article under the CC BY license (https://creativecommons.org/licenses/by/4.0/) DOI: https://dx.doi.org/10.22159/ijpps.2021v13i11.41277. Journal homepage: https://innovareacademics.in/journals/index.php/ijpps.

\section{INTRODUCTION}

There is increased incidence of peptic ulcer worldwide due to stressful lifestyle and eating habits which includes both gastric and duodenal ulcers. It is one of the most prevalent gastrointestinal tract diseases that affect a wide range of people globally [1]. Due to its high morbidity and mortality rates, peptic ulcer disease has been one of the leading causes of gastrointestinal surgery for over a century. The pathophysiology of peptic ulcer disease was attributed to the imbalance between the offensive factors (e. g. acid, pepsin, Helicobacter infection) and the defensive ones (e. g. bicarbonate, mucin, prostaglandins, nitric oxide and growth factors) [2]. The use of non-steroidal anti-inflammatory drugs (NSAIDs), irregular diet, emotional stress, excessive alcohol use and smoking are all the principal etiological factors associated with the peptic ulcer [3] Nowadays, the drug treatment of ulcers is commonly focused on the suppression of acid secretion and the enhancement of gastric protection [4]. However, more and more clinical evaluations on the drug treatment showed that tolerance was developed and also the incidence of relapses as well as side effects were increased, which made the efficacy of the treatment be arguable. Many of the existed medicines have limitations, especially when they were used against ulcers with complex etiologies [4].

The main approach to treat peptic ulcer disease is to relieve pain, heal the ulcer and prevent ulcer recurrence. Currently, efforts are on the research of a suitable treatment from natural product sources. A large number of species and herbs have been evaluated by various researchers for their anti-ulcer effects to achieve a favourable outcome [5]. A wide range of drug is currently available for the treatment of gastric ulcer which includes proton pump inhibitor, $\mathrm{H}_{2}$ blocker, antacid, and anti-cholinergic. The most common adverse effect of these drugs are hypergastrinemia, hypersensitivity, gynecomastia, impotence, arrhythmia and blood dyscaris such as thrombocytopenia and enteric infection (Clostridium deficile) [6] Hence till now there is no truly satisfactory medicine for the management of peptic ulcer and plant drugs are proven as effective and safe drugs for the management ulcers [6].

About 600 commercial preparations with claimed liver-protecting activity are available all over the world. About 100 Indian medicinal plants belonging to 40 families are used for herbal formulation [7]. The Tephrosia villosa Linn. is native to India and it is medicinally important and used in the traditional system for the treatment of liver ailments [8]. The Tephrosia villosa Linn. is commonly known as Sarapunkha and used in ayurvedic system of medicine as a memory enhancer, neuroprotective [9] and treatment many ailments. The leaves of this plants contains alkaloids, flavonoids, tannins and phenols [10] and are scientifically proved for its anti-diabetic [11] antiulcer [9], anti-anxiety [12], antioxidant [13] and many other pharmacological activities. The Phyto-constituents of plant leaves are capable of reducing liver toxicity due to their antioxidant properties but, the plant has not been scientifically investigated for evaluation of hepato-protective activity [14]. The Tephrosia is a genus of plant, pantropical taxa with about 400 species distributed chiefly in Asia, Africa, Australia and America ${ }^{7}$. About twenty-four species of Tephrosia were recorded in India. The genus is well known for its richness in prenylated flavonoids and is considered to possess insect repellant, larvicidal, piscicidal, antimicrobial and anticancer properties [8-10]. The Tephrosia villosa belongs to the genus was essentially used for the management of diabetes, ulcers, cancer, hyperlipidemia, hepatotoxicity and renal problems in the folklore medicine but doesn't have the scientific evidence for the same [12-14]. In view of this, the present study was undertaken to investigate the anti-ulcer properties of aqueous extracts of Tephrosia villosa (TVME) leaves against experimentally induced ulcers in wistar rats.

\section{MATERIALS AND METHODS}

\section{Collection and authentication of plant material}

The areal parts of Tephrosia villosa have been collected from Sri Venkateshwara university, Tirupati, India and dried under shade. The 
leaves were in the Tirupathi forest and authenticated by Dr. Madhava chetty Asst. Prof. Dept. of Botany and specimen herbarium (Voucher No.907) was preserved at institute herbarium library. The leaves were separated from other parts, washed, cleaned and dried for further use.

\section{Preparation of methanol extract of Tephrosia villosa}

The shade dried leaves were pulverized into powder and sieved through No. 22 mesh. About 350 g (appx.) of coarse powder was subjected to successive solvent extraction using petroleum ether, benzene, chloroform and methanol in soxhlet apparatus [15].

\section{Preliminary phytochemical investigation of methanol extract of Tephrosia villosa}

The preliminary phytochemical investigation for the methanol extract of Tephrosia villosa had been conducted as per the procedure prescribed by Khandelwal [16].

\section{Drugs and chemicals}

All the chemical and reagents used in the present study were of analytical grade and procured from following sources. The ethanol and asprin procured from Sigma-aldrich chemical Pvt. Ltd., Bangalore and Tween 80 was obtained from Nice chemicals Bangalore. All the other solvents and chemicals used for extraction and physiochemical investigation were as of analytical grade purchased from SD fine chemicals Pvt. Ltd. Bangalore.

\section{Animals}

The healthy albino wistar male rats were procured from Sri Venkateshwara Enterprises, Bangalore housed under standard conditions of temperature $(22 \pm 10 \mathrm{C})$, relative humidity $(55 \pm 10 \%)$, $12 \mathrm{hr}$ light/dark cycles and fed with a standard pellet diet (Amrut, Pranav Agro Industries Ltd., Sangli, India) and water ad libitum. After randomization into various groups and before initiation of the experiment, the rats were acclimatized for a period of $7 \mathrm{~d}$ under above said environmental conditions. The experimental protocol has been approved by the Institutional Animals Ethics Committee, IJAHSM, Bangalore (Ref. no. IJAHSM/IAEC/2014/03) with the permission from Committee for the Purpose of Control and Supervision of Experiments on Animals (CPCSEA), Ministry of Social Justice and Empowerment, Government of India.

\section{Acute oral toxicity studies}

The OECD guidelines 423 (up and down procedure) were used to determine acute oral toxicity for methanol extract of Tephrosia villosa. A starting dose used was $2000 \mathrm{mg} / \mathrm{kg}$ body weight p. o. of extract (TVME) was administered to 3 male rats, observed for $14 \mathrm{~d}$. The experiments were repeated again with the same dose level, $2000 \mathrm{mg} / \mathrm{kg}$ body weight p. o. of extracts for $3 \mathrm{~d}$ more, and observed for $14 \mathrm{~d}$ [17].

\section{Evaluation of anti-ulcer activity}

The methanol extract of Tephrosia villosa was evaluated against stress and aspirin induced ulcers and study design in both studies consisting of six groups of six animals in each group as follows.

\begin{tabular}{|c|c|}
\hline Group I: Normal & Treated with Normal Saline(2 ml/kg) \\
\hline $\begin{array}{l}\text { Group II: Vehicle } \\
\text { control }\end{array}$ & $\begin{array}{l}\text { Induced with ulcers and treated with } 2 \% \\
\text { tween } 20\end{array}$ \\
\hline Group III: & Induced with ulcers+Treated with omeprazole \\
\hline Standard & (10 mg/kg, p. o.) \\
\hline $\begin{array}{l}\text { Group IV: TVME } \\
(100 \mathrm{mg} / \mathrm{kg})\end{array}$ & $\begin{array}{l}\text { Induced with ulcers+Treated with ethanol } \\
\text { extract of Tephrosia villosa }(100 \mathrm{mg} / \mathrm{kg} \mathrm{p} . \mathrm{o})\end{array}$ \\
\hline Group V: TVME & $\begin{array}{l}\text { Induced with ulcers+Treated with ethanol } \\
\text { extract of Tephrosia villosa }(200 \mathrm{mg} / \mathrm{kg} \mathrm{p} \text { o) }\end{array}$ \\
\hline $\begin{array}{l}\text { Group VI: TVME } \\
(400 \mathrm{mg} / \mathrm{kg})\end{array}$ & $\begin{array}{l}\text { Induced with ulcers+Treated with ethanol } \\
\text { extract of Tephrosia villosa ( } 400 \mathrm{mg} / \mathrm{kg} \mathrm{p.} \mathrm{o} \text { ) }\end{array}$ \\
\hline
\end{tabular}

\section{Evaluation of anti-ulcer activity against stress ulcers}

Stress ulcers were induced by forcing the Wistar albino rats of either sex to swim in the glass cylinder containing water to the height of 35 $\mathrm{cm}$ maintained at $25{ }^{\circ} \mathrm{C}$ for $3 \mathrm{~h}$. After the drug treatment animals were allowed to swim in cold water for $4 \mathrm{~h}$. After this, the animals were killed with a high dose of anesthetic ether. Stomach of each rat were opened along the greater curvature and examined macroscopically for gastric erosions under a dissecting microscope $(10 \times)$. Gastric juice collected into centrifuge tubes and centrifuged at $1000 \mathrm{r} / \mathrm{min}$ for $10 \mathrm{~min}$ and the volume were noted. The number of ulcers were scored and percentage of protection and ulcer index were calculated [18-20].

\section{Evaluation of anti-ulcer activity against stress ulcers}

All the experimental animals were kept for overnight fasting and gastric ulcers were by administering absolute cold aspirin (150 $\mathrm{mg} / \mathrm{kg} \mathrm{p.} \mathrm{o).} \mathrm{All} \mathrm{the} \mathrm{extracts} \mathrm{and} \mathrm{standard} \mathrm{drug} \mathrm{omeprazole} \mathrm{were}$ administered orally prior to the administration of aspirin. One hour later, the animals were sacrificed by cervical dislocation and the stomachs were removed. Gastric acid was collected and its $\mathrm{pH}$ was determined. Stomachs were opened along the greater curvature and gently rinsed with water for subsequent scanning. The number of ulcers was scored and the percentage of protection and ulcer index were calculated $[18,20-22]$.

\section{RESULTS}

\section{Preliminary phytochemical study}

The percentage yield of the TVME was found to be $8.15 \% \mathrm{w} / \mathrm{w}$. The preliminary phytochemical investigation of the methanol extract of Tephrosia villosa reveals the presence of alkaloids, glycosides, poly phenols, flavonoids, tannins, steroids, and carbohydrates in the plant.

\section{Acute toxicity studies}

The methanol extract of Tephrosia villosa was safe up to dose of $2000 \mathrm{mg} \mathrm{kg}^{-1}$ b.w. and caused neither mortality nor any signs of clinical abnormality in the tested animals during the observation period of $14 \mathrm{~d}$ after administration of the highest dose. There was no considerable change in body weight before and after treatment of the experiment and no signs of toxicity were observed. When the experiments were repeated again with the same dose level, 2000 $\mathrm{mg} / \mathrm{kg}$ body weight p. o. of extracts for $3 \mathrm{~d}$ more, no changes were observed for $14 \mathrm{~d}$. As per the results obtained in acute oral toxicity study doses were selected as 100,200 and $400 \mathrm{mg} / \mathrm{kg}$ on the ratio $1 / 20^{\text {th }}, 1 / 10^{\text {th }}$ and $1 / 5^{\text {th }}$ respectively.

\section{Evaluation of antiulcer activity}

\section{Anti-ulcer activity against stress induced ulcers}

In the present study of stress-induced ulcer model, control animals have shown significant $(\mathrm{P}<0.001)$ no of ulcers and ulcer index compare to normal animals which have shown no ulcers and ulcer index. Administration of Standard drug omeprazole and TVME at medium and high dose have significantly $(\mathrm{P}<0.001)$ reduced number of ulcers formed and ulcer index when compare to vehicle control. Due to the reduction in number of ulcers and ulcer index, percentage of protection was significantly increased in therapeutic groups treated with standard drug and TVME. Effect of TVME at $100 \mathrm{mg} / \mathrm{kg}$ was not significant (table 1)

The significant increase in formation of ulcerated area and total acidity were observed in vehicle control animals due to stress. But there was significant $(\mathrm{P}<0.001)$ decrease in ulcerated area and total acidity found in omeprazole and TVME $(200 \mathrm{mg} / \mathrm{kg}$ and $400 \mathrm{mg} / \mathrm{kg})$ treated animals compare to vehicle control group. Hence the percentage of protected area was significantly increased in animals treated with omeprazole and TVME (table 1)

\section{Anti-ulcer activity against aspirin-induced ulcers}

Administration of aspirin has shown significant $(\mathrm{P}<0.001)$ no of ulcers and ulcer index in-vehicle control animals in the present study compare to normal animals, which have shown no ulcers and ulcer index. Administration of Standard drug omeprazole and TVME at medium and high dose have significantly $(\mathrm{P}<0.001)$ reduced number of ulcers formed and ulcer index when compared to vehicle control. Due to the reduction in number of ulcers and ulcer index, percentage of protection was significantly increased in therapeutic groups treated with standard drugs and TVME. (table 2) 
The formation of significant ulcerated area was observed and total acidity was significantly increased in vehicle control animals due to the administration of aspirin. But there was significant $(\mathrm{P}<0.001)$ decrease in ulcerated area and total acidity found in omeprazole and
TVME (200 mg/kg and $400 \mathrm{mg} / \mathrm{kg}$ ) treated animals compare to vehicle control group. Hence the percentage of protected area was significantly increased in animals treated with omeprazole and TVME (table 2).

Table 1: Effect of methanol extract of tephrosia villosa on stress induced ulcers

\begin{tabular}{|c|c|c|c|c|c|c|c|}
\hline Group & $\begin{array}{l}\text { Number of } \\
\text { ulcers }\end{array}$ & Ulcer Index & $\begin{array}{l}\text { Percentage } \\
\text { of inhibition }\end{array}$ & $\begin{array}{l}\text { Percentage of } \\
\text { ulcerated area }\end{array}$ & $\begin{array}{l}\text { Percentage of } \\
\text { protected area }\end{array}$ & pH & Total acidity \\
\hline Group I: Normal & 0 & 00 & 100 & 0 & 100 & $3.776 \pm 0.1151$ & $40.48 \pm 0.6388$ \\
\hline $\begin{array}{l}\text { Group II: Vehicle } \\
\text { control }\end{array}$ & $6.400 \pm 0.5099$ & $28.56 \pm 1.776$ & 00 & $69.54 \pm 1.238$ & 30.46 & $1.906 \pm 0.09745$ & $72.81 \pm 1.691$ \\
\hline Group III: Standard & $1.600 \pm 0.2449$ & $3.930 \pm 0.3035$ & $86.239 \pm 6.391$ & $21.90 \pm 1.690$ & 78.1 & $3.822 \pm 0.1680$ & $42.69 \pm 1.349$ \\
\hline $\begin{array}{l}\text { Group IV: } \\
\text { TVME(100 mg/kg) }\end{array}$ & $4.800 \pm 0.284$ & $22.45 \pm 2.200$ & $25.34 \pm 4.93$ & $53.64 \pm 1.959$ & 46.36 & $2.108 \pm 0.0779$ & $61.06 \pm 3.557$ \\
\hline $\begin{array}{l}\text { Group V: TVME } \\
(200 \mathrm{mg} / \mathrm{kg})\end{array}$ & $2.80^{* * \pm 0.735}$ & $14.75^{* *} \pm 1.124$ & $48.19^{* *} \pm 3.29$ & $41.94^{* *} \pm 0.9020$ & $58.06^{* *}$ & $\begin{array}{l}3.388^{* *} \pm 0.100 \\
9\end{array}$ & $51.17^{* * \pm 1.274}$ \\
\hline $\begin{array}{l}\text { Group VI: TVME } \\
(400 \mathrm{mg} / \mathrm{kg})\end{array}$ & $\begin{array}{l}2.200^{* * *} \pm 0.34 \\
5\end{array}$ & $\begin{array}{l}4.505^{* * *} \pm 0.65 \\
62\end{array}$ & $85.83^{* * *} \pm 5.67$ & $25.29 \pm 2.033^{* * *}$ & $74.71^{* * *}$ & $\begin{array}{l}4.003^{* * *} \pm 0.18 \\
86\end{array}$ & $\begin{array}{l}40.58^{* * *} \pm 0.70 \\
49\end{array}$ \\
\hline
\end{tabular}

Values are mean \pm SEM, $\mathrm{n}=6$ symbols represent statistical significance, ${ }^{\mathrm{n}} \mathrm{p}>0.05,{ }^{*} \mathrm{p}<0.05,{ }^{* *} \mathrm{p}<0.01,{ }^{* * *} \mathrm{p}<0.001$ vs diabetic control. ${ }^{\mathrm{ns}} \mathrm{p}>0.05,+\mathrm{p}<0.05,{ }^{+} \mathrm{p}<0.01,{ }^{++} \mathrm{p}<0.001$ normal control vs positive control.

Table 2: Effect of methanol extract of Tephrosia villosa on aspirin induced ulcers

\begin{tabular}{|c|c|c|c|c|c|c|c|}
\hline Group & $\begin{array}{l}\text { Number of } \\
\text { ulcers }\end{array}$ & Ulcer Index & $\begin{array}{l}\text { Percentage } \\
\text { of inhibition }\end{array}$ & $\begin{array}{l}\text { Percentage of } \\
\text { ulcerated area }\end{array}$ & $\begin{array}{l}\text { Percentage of } \\
\text { protected area }\end{array}$ & pH & Total acidity \\
\hline Group I: Normal & 0 & 00 & 100 & 0 & 100 & $3.866 \pm 0.1080$ & $41.54 \pm 0.6759$ \\
\hline $\begin{array}{l}\text { Group II: Vehicle } \\
\text { control }\end{array}$ & $7.2 \pm 0.5831$ & $28.49 \pm 2.243$ & -- & $70.23 \pm 1.392$ & 29.77 & $1.808 \pm 0.1022$ & $75.85 \pm 2.486$ \\
\hline Group III: Standard & $1.8 \pm 0.2000$ & $4.216 \pm 0.5368$ & $85.20 \pm 3.77$ & $24.37 \pm 2.106$ & 75.63 & $3.592 \pm 0.2051$ & $41.69 \pm 1.008$ \\
\hline $\begin{array}{l}\text { Group VII: } \\
\text { TVME(100 mg/kg) }\end{array}$ & $\begin{array}{l}5.120 \pm 0.35 \\
1\end{array}$ & $21.69 \pm 0.4460$ & 25.335 & $53.03 \pm 2.634$ & 46.97 & $\begin{array}{l}2.163 \pm 0.0768 \\
8\end{array}$ & $58.45 \pm 3.409$ \\
\hline $\begin{array}{l}\text { Group VIII: TVME } \\
(200 \mathrm{mg} / \mathrm{kg})\end{array}$ & $\begin{array}{l}2.667^{* *} \pm 0.5 \\
7\end{array}$ & $15.05^{* *} \pm 2.92$ & $48.192^{* *}$ & $41.16^{* * \pm 0.634}$ & $58.84^{* *}$ & $3.457^{* *} \pm 0.10$ & $50.96^{* *} \pm 1.77$ \\
\hline $\begin{array}{l}\text { Group IX: TVME } \\
(400 \mathrm{mg} / \mathrm{kg})\end{array}$ & $\begin{array}{l}2.333^{* * *} \pm 0 . \\
311\end{array}$ & $\begin{array}{l}4.117^{* * * \pm 1.53} \\
2\end{array}$ & $85.827^{* * *}$ & $25.07^{* * *} \pm 2.859$ & $74.93^{* * *}$ & $\begin{array}{l}3.833^{* * *} \pm 0.1 \\
178\end{array}$ & $\begin{array}{l}40.90^{* * *} \pm 0.888 \\
3\end{array}$ \\
\hline
\end{tabular}

Values are mean \pm SEM, $\mathrm{n}=6$ symbols represent statistical significance. ${ }^{\mathrm{ns}} \mathrm{p}>0.05, * \mathrm{p}<0.05, * * \mathrm{p}<0.01, * * * \mathrm{p}<0.001$ vs diabetic control. ${ }^{n s} \mathrm{p}>0.05,+\mathrm{p}<0.05,+{ }^{+} \mathrm{p}<0.01,{ }^{++} \mathrm{p}<0.001$ normal control vs positive control.

\section{DISCUSSION}

The causative factors that may produce ulcer in the human being are several they are stress, chronic use of anti-inflammatory drugs and continuous alcohol ingestion, spicy food among others. In most of cases, the exact causative factor of ulcer is unknown, but it is generally accepted that it is the result of an imbalance between aggressive factors and defensive factors that mucosal maintenance integrity through the several endogenous mechanisms. Peptic ulcer is leading cause of mortality and morbidity in developing countries, characterized by an imbalance between aggressive gastric luminal factor and defensive mucosal barrier. This disease is mainly associated with an increase in gastric acid secretion. Numerous factors like diet, smoking, drugs like aspirin and infection are responsible for the augmentation of ulcers. Still, no therapeutic intervention has been found successful. So, in the present study, efforts has been made to review and to explore various animal models to find out a suitable medication for the treatment of peptic ulcer [24-26]

Tephrosia villosa are employed in the treatment and management of ulcers in folklore medicine, but still no complete curative treatment is available. So this review has been designed to explore the effects of Tephrosia villosa extracts for the treatment of peptic ulcers against various ulcer models like pyloric ligation; ethanol and aspirin-induced ulcer models.

In the present study, oral administration of methanol extract Tephrosia villosa at $200 \mathrm{mg} / \mathrm{kg}$ and $400 \mathrm{mg} / \mathrm{kg}$ significantly inhibited gastric ulcer formation in both selected ulcer models when compared control and effect was comparable to standard omeprazole.
Aspirin is commonly used for inducing ulcer in experimental rats due to its intense gastric mucosal damage. Studies suggest that the Aspirin damage to the gastrointestinal mucosa starts with microvascular injury, namely disruption of the vascular endothelium resulting in increased vascular permeability, edema formation and epithelial lifting [27-29].

Aspirin is an NSAID its abuse will induce gastric ulceration by inhibition of gastric cyclo-oxygenase resulting in the formation of prostacyclin, which is the predominant prostanoid produced in the gastric mucosa. The ulcers produced can be prevented by exogenous $\mathrm{PGE}_{2}$ and $\mathrm{PGI}_{2}[30,31]$.

The significant decrease in gastric ulcer, ulcer index, ulcerated area and total acidity was observed animals in pretreated methanol extract compared to the vehicle control group. In the present study, we also found that there is a significant rise in percentage inhibition of ulcer formation, protected area and $\mathrm{pH}$ of gastric content. The antiulcer potentials of plant extracts were almost similar to the standard drug omeprazole used in the present study.

The stress produces stimulate vagus that increases the release of acetylcholine which ultimately produces nitric oxide responsible for the development of ulcers in the stomach due to free radical nature. The other ulcerogenic aspirin used in the present study directly irritate GIT mucosa and acts as free radical results in the formation of peptic ulcers. Hence the drugs those possess antioxidants can be good approaches for the treatment of ulcers due to the presence flavonoids and phenolic compounds. In this regard, the study can be performed to evaluate the antioxidant properties of the plant to determine the possible mechanism $[32,33]$. 
The methanol extract of Tephrosia villosa possess significant antiulcer property against stress and aspirin-induced ulcers. The further investigation should be performed to isolate and evaluate specific constituents responsible for the antiulcer activity.

\section{CONCLUSION}

The present study was undertaken for the investigation of antiulcer activity of methanol extracts of Tephrosia villosa against stress and aspirin-induced ulcers in animal model. From the results obtained from the study, it can be concluded that methanol extract of the plant exhibited a strong gastroprotective activity against experimentally induced ulcers. However further investigation required establishing the clear mechanism of action of the extract and also to isolate individual phytoconstituents present in Tephrosia villosa that may be responsible for these beneficial therapeutic effects.

\section{ACKNOWLEDGEMENT}

The authors of manuscript are thankful to The Principal and management of East-West College of Pharmacy, Bangalore for providing facilities to conduct this research work.

\section{FUNDING}

Nil

\section{AUTHORS CONTRIBUTIONS}

The present research work was designed by Dr. Ramesh C. The experiment was performed by Mrs. Pinkey Rawal and Ms. Shabana S under the supervision of Dr. Soma Pramanik.

\section{CONFLICT OF INTERESTS}

Declared none

\section{REFERENCES}

1. Hussain L, Akash MS, Naseem S, Rehman K, Ahmed KZ. Antiulcerogenic effects of salmalia malabarica in the gastric ulceration-pilot study. Adv Clin Exp Med. 2015;24(4):595-605. doi: 10.17219/acem/28115, PMID 26469103.

2. Scanlon VC, Sanders T. Essential of anatomy and physiology. 5th ed. Philadelphia: F. A. Davis company; 2007. p. 396.

3. Toma W, Hiruma Lima CA, Guerrero RO, Brito AR. Preliminary studies of Mammea americana L. (Guttiferae) bark/latex extract point to an effective antiulcer effect on gastric ulcer models in mice. Phytomedicine. 2005;12(5):345-50. doi: 10.1016/j.phymed.2003.06.009, PMID 15957368.

4. Al-Yahya MA, Rafatullah S, Mossa JS, Ageel AM, Al-Said MS, Tariq M. Gastric antisecretory, antiulcer and cytoprotective properties of ethanolic extract of Alpinia galanga willd in rats. Phytother Res. 1990;4(3):112-4. doi: 10.1002/ ptr.2650040308.

5. Santin JR, Lemos M, Klein Junior LCK, Niero R, de Andrade SF. Antiulcer effects of Achyrocline satureoides (Lam.) DC (Asteraceae) (Marcela), a folk medicine plant, in different experimental models. J Ethnopharmacol. 2010;130(2):334-9. doi: 10.1016/j.jep.2010.05.014, PMID 20546870.

6. Saldanha CJ, Singh BG. Leguminosae. In: Saldanha CJ, editor Flora of Karnataka. Vol. I. Oxford and IBH; 1984. p. 495-9.

7. Sarin JPS, Singh S, Garg HS, Khanna NM, Dhar MMA. Flavonol glycoside with anticancer activity from Tephrosia candida. Phytochemistry. 1976;15(1):232-4. doi: 10.1016/S00319422(00)89101-3.

8. Yuh-Lin C. New piscicidal flavonoids from Tephrosia obovata merr. Asian J Pharm. 1978;3(4):18.

9. Bentley MD, Hassanali A, Lwande W, Njoroge PEW, Yatagai M. Insect anti feed ants from Tephrosia elata Deflers. Insect Sci Appl. 1987;8(1):85-8.

10. Gokhale AB, Saraf MN. Tephrosia purpurea, a review of contemporary literature and medicinal properties. Indian Drugs. 2000;37:12.

11. Kapoor SL, Kapoor LD. Medicinal plant wealth of the Karimnagar District of Andhra Pradesh. Bull Ethnobotanical Res. 1980;1:120-44.
12. Jain SR, Sharma SN. Hypoglycaemic drugs of Indian indigenous origin. Planta Med. 1967;15(4):439-42. doi: 10.1055/s-00281100005, PMID 5603487.

13. Ramadhani SON, Zakaria HM, Abdul WK, Ester MI, Matobola JM, Paul E, Mainen JM. Larvicidal, antimicrobial and brine shrimp activities of extracts from Cissampelos mucronata and Tephrosia villosa from coast region, Tanzania. BMC Comp Alt Med. 2011;11:33.

14. Sayed DA, Fahmy SR, Soliman AM, Hussein NS. Antiulcerogenic efficacy of ethanolic extract of Vitis vinifera leaves in rats. Int J Pharm Pharm Sci. 2016;8(9):163-72. doi: 10.22159/ijpps.2016v8i9.12846.

15. Kokate CK. Practical pharmacognosy. New Delhi, Vallabh Prakashan. 1994;4:110-1.

16. Khandelwal KR. Practical pharmacognosy-techniques and experiments. Pune; NiraliPrakashan; 2000.

17. Trease GE, Evans MC. Text book of pharmacognosy London. Bailliare Tindall. 1983;12(193):336.

18. OECD. Acute oral toxicity-acute oral toxic class method. Guideline 423, adopted 23.03.1996. In: Eleventh addendum to the OECD guidelines for the testing of chemicals. Paris: Organization for Economic Co-operation and Development; 2000.

19. Vogel H. Drug discovery and evaluation pharmacological assays.2 ${ }^{\text {nd }} .2002$ ed. New York: Springer-Verlag Berlin Heidelberg; 2002. p. 870-5.

20. Aitken J, Fisher H. Reactive oxygen species generation and human spermatozoa: the balance of benefit and risk. Bioessays. 1994;16(4):259-67. doi: 10.1002/bies.950160409, PMID 8031303.

21. Rasika DB, Mahendra A, Sneha JA, Subodh CP. Antiulcer activity of the ethanol extract of leaves of Sesbania grandiflora (linn.). Int J Pharm Pharm Sci. 2010;2(4):206-8.

22. Vanita K, Deepali M. Evaluation of antipyretic and antiulcer activity of ethanolic extract of leaves of Alstonia scholaris 1 . in albino wistar rats. Asian J Pharm Clin Res. 2012;12(12):203-8.

23. Agrawal R, Garg HK, Garg U, S Mgh Sk. Antiulcer activity of Smithia conferta in various animal. J Sand Chem Soc. 2010;14:307-10.

24. Shreedhara CS, Aswatha Ram HN, Sachin B, Zanwar. Free radical scavenging activity of aqueous root extract of Argyreia nervosa. J Nat Rem. 2009;9:216-23.

25. Van JR. Inhibition of prostaglandin synthesis as a mechanism of action of aspirin-like drugs. Nature. 1971;235:231-5.

26. Szabo S, Trier JS, Brown A, Schnoor J. Early vascular injury and increased vascular permeability in gastric mucosal injury caused by ethanol in the rat. Gastroenterology. 1985;88(1 Pt 2):228-36. doi: 10.1016/s0016-5085(85)80176-1, PMID 3871087.

27. Konturek SJ, Piastucki I, Brzozowski T, Radecki T, Dembińska Kiec A, Zmuda A, Gryglewski R. Role of prostaglandins in the formation of aspirin-induced gastric ulcers. Gastroenterology. 1981;80(1):49. doi: 10.1016/0016-5085(81)90182-7. PMID 7450410.

28. Schubert ML. Pharmacotherapy for acid/peptic disorders. Yale J Biol Med. 1996;69(2):197-201. PMID 9112751.

29. Bhattacharya SK, Bhattacharya A, Kumar A, Ghosal S. Antioxidant activity of Bacopa monniera in rat frontal cortex, striatum and hippocampus. Phytother Res. 2000;14(3):174-9. doi: 10.1002/(sici)1099-1573(200005)14:3<174::aid-ptr624>3.0.co;2o, PMID 10815010.

30. Rao ChV, Ojha SK, Radhakrishnan K, Govindarajan R, Rastogi S, Mehrotra S, Pushpangadan P. Antiulcer activity of Utleria salicifolia rhizome extract. J Ethnopharmacol. 2004;91(23):243-9. doi: 10.1016/j.jep.2003.12.020, PMID 15120446.

31. Cochran T, Stefanko J, Moore C, Saik R. Dimethyl sulfoxide protection against gastric stress ulceration. Curr Surg. 1983;40(6):435-7. PMID 6653164.

32. Kunchandy E, Rao MNA. Oxygen radical scavenging activity of curcumin. Int J Pharm. 1990;58(3):237-40. doi: 10.1016/03785173(90)90201-E.

33. Malfertheiner P, Chan FK, McColl KE. Peptic ulcer disease. Lancet. 2009;374(9699):1449-61. doi: 10.1016/S01406736(09)60938-7, PMID 19683340.

34. Govindarajan R, Rastogi S, Vijayakumar M, Shirwaikar A, Rawat AK, Mehrotra S, Pushpangadan P. Studies on the antioxidant activities of Desmodium gangeticum. Biol Pharm Bull. 2003;26(10):1424-7. doi: 10.1248/bpb.26.1424, PMID 14519948. 